\title{
JUURNAL.RU
}

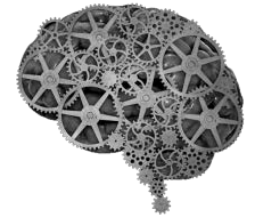

COMPANY GROUP "INTELLEKT"

Кобзев Е.А. Магнитогорский государственный технический университет им. Г.И. Носова Магнитогорск, Россия

doi: 10.18411//j2016-9-3-06

idsp 000001: lj2016-18-3-06

\section{История развития личности, употребляющей никотин}

\section{Аннотация}

Употребление никотина индивидами, сочетается с проявлениями у них поведенческих, психических расстройств. Ряд исследователей, считают проявления нервно - психической патологии, как результат исторического развития личности $[1 ; 2 ; 4 ; 7]$. Таким образом употребление табака - это процесс исторического становления личности с раннего детсткого возраста. Развитие личности табакокурильщика происходит в сочетании с невротическими проявлениями и патологииями характера развивающейся личности. С раннего детского возраста индивидам, употребляющим никотин, свойственны субъективные и аффективные черты характера.

\section{Kobzev Evgeni Anatolyevich}

The history of the development of personality, uses nicotine

\section{Abstract (1)}

The use of nicotine combined with behavioral manifestations, mental disorders in individuals. Some researchers believe that the manifestations of nervous and mental diseases are the result of the historical development of the personality $[1 ; 2 ; 4 ; 7]$. Tobacco use - a process of historical development of the personality from an early age detstkogo. Personal development takes place in conjunction with neurotic symptoms and character pathology developing personality tabakokurilschika. Subjective and affective traits characteristic of individuals who use nicotine from early childhood. 
С точки зрения авторов, $[5 ; 9 ; 10]$ употребление психоактивных веществ индивидами, в том числе никотина, сочетается с проявлениями у них поведенческих, психических расстройств. Ряд исследователей, считают проявления нервно - психической патологии как результат исторического развития личности $[1 ; 2 ; 4 ; 7]$. К основным предикторам формирования аддикций относятся невротические проявления и патологии характера развивающейся личности. При невротическиом развитии обращают на себя внимание, прежде всего, эмоциональная чувствительность и выраженность чувства «я». В первом случае эмоциональная чувствительность проявляется повышенной потребностью в эмоциональном контакте. Неудовлетворение этих потребностей порождает у детей с неврозами страх одиночества или страх неразделённости чувств, эмоционального неприятия и изоляции. Во втором случае выраженность «я» - это рано проявляемое чувство собственного достоинства, стремление к своему мнению, самостоятельности в занятиях и действиях. Чрезмерные ограничения активности и самостоятельности создают аффект блокирования потребностей в самовыражении, самореализации и утверждении своего «я» [ 4 ].

С раннего детского возраста невротической личности свойственны субъективные и аффективные черты характера: импульсивность, кататимность, эгоцентризм, сензитивность, фантастичность и т.д. [ 7 ]. В. И. Гарбузов к основными преморбидными характерологическим образованиям, способствующим развитию невроза личности с раннего детства, относит: «агрессивность», «честолюбие», «педантичность», «благоразумность», «тревожную синтонность», «инфантильность”, “психомоторную нестабильность», «конформность”, “зависимость», «тревожную мнительность и замкнутость». Особое значение автор придаёт характерологическому радикалу «контрастности». Его характеризует противоречивость всех личностных характеристик: внеше горд, силён, самоуверен - внутренне раним, обидчив; драчун, агрессивен - в то же время робок, боязлив; стремление к лидерству и неверие в свои силы, пассивность; презрительное отношение к сверстникам и сверхчувствительность к их оценке его личностных достоинств; при правдолюбии и требовательности искренности от других - скрытность, недоверчивость и подозрительность; при страхе заболевания и смерти 
родителей, высокой степени озабоченности их делами - грубое, неласковое к ним отношение [11].

Среди прочего, речь идёт об упрямстве. Упрямство ребёнка или подростка, характеризует его субъективизм в поведении, сознательную и неосознаваемую конфронтацию и сопротивление социальным правилам взаимодействия. Это свойство является отражением нарушения регуляции процессов торможения и возбуждения нервной системы, что будет являться психофизиологическим основанием дезадаптивности личности. Данная черта характера, присваиваемая детьми, может служить основанием для самооценивания, способствовать фиксации определённых способов деятельности и психического реагирования, которые могут привести к формированию невротизации личности. [4, с. 152]. Исследования позволяют утверждать, что курильщики систематически, употребляющие никотин, с детского возраста являются, значимо в большей степени, упрямыми индивидами, чем некурящие. Более того, испытуемые, употребляющие никотин, значимо в большей степени, не желают подражать различным личностям, при формировании собственной идентичности в подростковом и юношеском возрасте, являются консерваторами [6]. Это может говорить в пользу ригидности установок восприятия личности аддикта и её невротичности.

Выделяются два типа развивающейся с детства невротической личности, которые, с большой долей вероятности, начнут употреблять никотин в подростковом и юношеском возрасте. К первому типу можно условно отнести формирующихся имплозивных «невротических» индивидов. Для них характерны: высокая степень впечатлительности, возбудимость, пугливость, импрессивность. Эти качества сочетаются с чувством ответственности, хорошим пониманием социальных нормативов. В процессе своей жизнедеятельности, социализации эти дети часто склонны к интровертированности, фиксации на не приятных переживаниях [ 4].Типичным и существенным в патогенезе невроза индивидов второго типа является сочетание упорной настойчивости с агрессивной возбудимостью. Здесь имеется воспитанная склонность не считаться с окружающими, подчинять их себе. Чем прочнее условиями воспитания закрепляется этот стереотип, тем труднее взаимодействие с 
окружающими, тем меньше проявляется разумной уступчивости и тем больше конфликтных ситуаций и срыва [ 7].

Основным фактором в развитии невротических проявлений и нарушений характера развивающейся личности детей следует рассматривать в отсутствии или недостаточности курационно-поддерживаемой практики родителей [3]. Проблемы эмоционального контакта с родителями у детей, которые впоследствии заболевают неврозами и станут употреблять в юности никотин обусловлены, прежде всего, гиперсоциальной направленностью личности матери в виде гипертрофированного чувства долга, обязанности, повышенной принципиальности, трудности компромиссов. Типичны затруднения и в эмоциональном плане с отцом в виду его занятости, недостаточной включённости в воспитание.

Родители имеют ригидные способы отношения восприятия собственных детей, нередко не признают их автономии, уникальности [ $4 ; 8 ; 11$ ].

\section{Литература:}

1. Бунькова К. М. Депрессии и неврозы: руководство для врачей / К. М. Бунькова - М. : Медиа, 2011. - С.15 - 16.

2. Гарбузов В. И. Неврозы у детей / В. И. Гарбузов, Ю.А. Фесенко. - СПб. : К APO, 2013. - 336 c.

3. Джонсон С. М. Психотерапия характера. Методическое пособие для слушателей курса «Психотерапия» / С. М. Джонсон. - М. : Центр психологической культуры, 2001. - 356с.

4. Захаров А. И. Происхождение детских неврозов и психотерапия /А. И. Захаров. - М. :ЭКСМО - Пресс, 2000. - 448c. 
5. Змановская Е. В. Девиантное поведение личности и группы: учеб. пособие для вузов / Е. В. Змановская, В. Ю. Рыбников. - СПб. [и др.]. - Питер, 2011. $-351 \mathrm{c}$.

6. Корнетов А.Н. Клинико-психологические и психобиографические факторы риска зависимости от никотина в юношеском возрасте /А.Н. Корнетов, Е.А. Кобзев // Ученые записки университета им. П.Ф. Лесгафта. - 2016. - № 3 (133). - С. 287-291.

7. Мясищев В. Н. Личность и неврозы / В. Н. Мясищев. - Л. :Изд. ЛГУ, 1960. $-428 \mathrm{c}$.

8. Никитенко М. А. Особенности детско-родительских отношений у лиц с зависимостью от табакокурения / М. А. Никитенко, А. В. Шаболтас //Вестник Санкт-Петербургского университета. Сер. 12, Психология. Социология. Педагогика. - 2011. - Вып. 3. - С. 207-213.

9. Особенности психопатии при табачной зависимости / В. К. Смирнов и [ и др. ] // Журнал неврологии и психиатрии им. С. С. Корсакова. - 1991. T.91, №2. - С. 93-96.

10. Руководство по аддиктологии / под ред. В. Д. Менделевича. - СПб. : Речь, 2007. $-768 \mathrm{c}$.

11. Спиваковская А. С. Профилактика детских неврозов (комплексная психологическая коррекция) / А. С. Спиваковская. - М. : Изд-во МГУ, 1988. - 200c. 